\title{
Research on Early-warning and Countermeasures of Financial Risk in Universities
}

\author{
Feng Pan ${ }^{1, a}$, Hui Pan ${ }^{2, b}$, Ruixiang Ou ${ }^{2, c}$, Yao Huang ${ }^{3, d}$ \\ ${ }^{1}$ Financial Department of South China University of Technology, Guangzhou, 510640, China \\ ${ }^{2}$ Library of South China University of Technology, Guangzhou, 510640, China \\ ${ }^{3}$ Propaganda Department of Southern Medical University, Guangzhou, 510515, China \\ ${ }^{a}$ email, ${ }^{b}$ email, ${ }^{c}$ email, ${ }^{\text {demail }}$
}

Keywords: Financial risk in universities, Risk early-warning, Countermeasures research

\begin{abstract}
With the financial risk in universities is becoming more and more prominent, the correct evaluation of the early warning mechanism of financial risk and the proposition of the feasible evaluation methods of financial risk in universities is one of the important and urgent research directions. This paper analyzes the causes of the financial risk, expounds the design principles and specific requirements of early-warning indexes of financial risk in universities. From the perspectives of debt paying ability, operational performance ability, income ability and development ability, the paper establishes the early-warning system of financial risk in universities and puts forward prevention and control measures of financial risk in universities.
\end{abstract}

\section{Reasons for Financial Risk in Universities}

New Campus Construction due to Expanding Enrollment. Since the enrollment expansion, the number of students in colleges and universities has increased year by year. The construction of new campus and research facilities in some universities and colleges are implemented in the condition of in-debt management. However, the university or college does not reach the level of putting up new specialty or establishing new schools. It not only wastes the capital cost of universities, but also restricts the further development of the university. After the enormous land expenditure of basic construction of universities, the universities always cannot meet the demand of infrastructure construction funds. The loans become the first choice. The commercial credit loan is to solve the land requisition, funds for the new campus, infrastructure construction and housing construction for the purpose of scientific research. The huge demand for funds produce high interest rates of a large number of large loans.

Huge Investment for the Improvement of Teaching Conditions. If universities want to develop in a long term and improve their teaching quality, they must optimize the existing educational conditions. All the optimization needs a lot of money. In recent years, the ministry of education in China has carried out undergraduate teaching evaluation work. The ministry of education has clearly defined the teaching investment evaluation indicators, including the students' teaching equipment value, the campus area, the average size of the sports field, the land area of per student and other new evaluation indicators. Under the premise of the expansion of students' enrollment, the primary task of creating economies of scale and ensuring the passing the assessment of the university is to increase the investment in the construction of teaching infrastructure. The main purpose of adopting financial credit loan is to ensure that the university can pass through undergraduate evaluation. However, huge scale debt and high interest rates are great burdens for colleges and universities.

Relatively Declining Financial Appropriation. Over the years, although the state or local financial investment in higher education funds has increased year by year, the increase rate is not high. Especially for combined colleges of provinces, students of expanded enrollment have not got proper financial allocations, which have greatly affected the survival of colleges. Some of the funds have been overrun every year, and the basic constructions cannot obtain the financial investment of the 
government. It is built with bank credit and university self-financing. As a result, the university is facing the huge financial pressure.

Lacking Resources of Other Income. Universities are different from enterprises. Enterprises aim at profit, while universities should not engage in commercial activities to repay debts through profit. Most colleges and universities have some investment projects and economic entities. However, there are different functional departments in management. Irregular operating system, management system, inappropriate mechanism, unclear property relations often appear in the logistics centers, infrastructure departments, offices and other departments. These phenomena make it difficult for high-tech achievement transforming into realistic products. The self-development of the enterprise run by the university is greatly restricted.

Human Expenditure and Increasing Interest Expenditure. In recent years, colleges and universities have implemented the performance wage reform, and improved the welfare of staff in order to stabilize talents of colleges and universities. Colleges and universities increase their liabilities year by year, and interest costs occupy normal expenses. It is an important factor of the cash flow difficulties in universities. There is also the financial risk of repayment of principal loans.

\section{Design Principles and Specific Requirements of Early-warning Indexes of Financial Risk in Universities}

Design Principles. University financial risk should be different from enterprise financial risk. The enterprise is a profit-making organization, and the university is a non-profit organization. Profit income only protects the normal development of university, not simply for profit. The incorrect assessment of own solvency will result in the debt which cannot be repaid in time. Therefore, the financial risk of raising money can also be said to be the financing risk. The key internal reason of university financial risk lies in the design of early warning index system of financial risk. The measurement of financial risk indicators should be weighed from the perspective of internal financial risk, which is an effective way to master the nature of financial risk. The process of designing financial early-warning indicators must adhere to the dynamic principle. The design must adapt itself to the development of society. When the policy changes, we should supplement the causes of financial risks and try to nip them in the bud as early as possible. Financial early warning indicators can reflect the financial situation of colleges and universities, which reminds the leadership to take correct precautions.

Specific Requirements. University financial risk refers to the bad influence brought by finance. The evaluation of financial risk is only to measure and evaluate the risk so as to test the degree of financial risk of the university. The study object is financing, investment, management and distribution of capital flows. The circulation of funds is not for profit. The capital growth rate is too slow. We should select the evaluation index which can reflect the characteristics of university financial risk.

\section{System Establishment of Early-warning Indexes of Financial Risk in Universities}

Index of Debt Paying Ability. It is a manifestation of a university's ability to pay its debts. We can take the asset liability ratio, real payment ratio, liquidity ratio, debt to income ratio, debt interest rate, long-term debt to total debt ratio, debt ratio, turnover time to evaluate the solvency. The indicators include asset liability ratio, short-term solvency, liquidity ratio, the actual payment ratio, income and liabilities ratio, potential payment ratio, the rate of monetary fund protection and the proportion of cumulative loans to total income.

Index of Operational Performance Ability. Property and capital support the development of teaching and research institutions in universities. If the property and capital do not meet the expected goals, there will be a certain impediment to the financial management of colleges and universities. Universities can choose the indexes to reflect the proportion of tuition fees, income and expenditure, operating capacity of income and expenditure, the proportion of public expenditure, the ratio of 
profitability, the growth rate of fixed assets as indicators. Indicators include the income and expenditure ratio, average tuition income expenditure ratio, public expenditure ratio, the growth rate of fixed assets, the university self-income ability, funds expenditure income ratio, university property investment return and investment and pay capacity in infrastructure construction.

Index of Income Ability. After the transformation from planned economy to free economy, colleges and universities must adapt to the development of free economy. Colleges and universities should give full play to their own advantages and provide excellent talents for society. At the same time, colleges receive the best earnings from starting schools. We select the university profitability indicators, such as net asset yield, total asset yield, education fees of qualified students, workers' per capita net income, return on investment and other related indicators. The indicators should include the total assets income rate, net asset income ratio, investment income ratio, non-financial contribution of per student, self-income capacity ratio, teachers' research funding per capita and staff contribution rate.

Index of Development Ability. This index can reflect the continuous development ability of a university. If the university lacks sufficient ability, the future financial risk will increase. We select indexes that indicate their ability to develop, such as the level of the use of their own funds, the equity ratio of assets, the balance of their own funds as a proportion of monetary funds, and the extent to which other funds are occupied. The index includes the asset equity ratio, the use of its own funds, other funds occupancy levels of its own funds, currency funds accounted for the balance at the end of the year, the proportion of net asset growth rate, the growth rate of fixed assets, funds occupation and the increase revenue rate.

\section{Prevention and Control Measures of Financial Risk in Universities}

Strengthen Risk Awareness and Establish Effective Mechanism. The university can construct the management system of economic responsibility which combines responsibility, power and benefit. No matter which link has gone wrong, we can find the specific responsible person. Our financial work should strictly adhere to the principle of authenticity and preciseness. Combine the appraisal mechanism with the economic responsibility system. The incentive mechanism is adopted for the excellent staff. Enhance the sense of responsibility of the school leadership. Strengthen the economic responsibility system of the independent legal person of the university. Design a relatively complete combination system of power, responsibility and benefit. Strictly establish the system of auditing and administration during the tenure of the leadership. We must strengthen the awareness of risk prevention. Guide the permeation of risk awareness into the usual financial work, especially infrastructure investment. Colleges and universities cannot all rely on bank loans.

Reinforce the Construction of Internal Control System and Strengthen Financial Management. According to the relevant rules and regulations issued by the ministry of finance, financial management must establish the early warning system of the financial risk conforming to the university's own characteristics and operating features and implement it strictly. Clarify the division of responsibility. The cashier and the accountant should help each other and cooperate closely together to take care of the daily financial work. Their work should follow the principle of "the cashier is responsible for the money and the accountant is responsible for the bill". Strictly formulate the relevant system of university bidding to avoid the use of the post of economic crimes in order to achieve the safety of university capital operation. Strengthen financial management to improve the scientific and rational operation of capital. First, to implement the centralized treasury payment system, strictly regulate the financial expenditure activities, strengthen supervision and management for state funding and improve running efficiency of capital and the exercise effect. Second, establish the university internal capital management mechanism to realize the centralized control of the university internal capital. Only the institution can exercise the financial authority in the whole university. The secondary level colleges and departments should set up the accounts under the supervision of the administrative institution, which can not only speed up the capital turnover rate, but also avoid excessive idle capital. 
Control Loan Amount Reasonably and Optimize Loan Structure. There is a close association between universities and banks. Low cost financing brings benefits to universities, and is also mutually beneficial for banks. Universities and banks should reach a common agreement. According to the university's own factors, universities should scientifically and rationally develop loans model, loans amount and the loans maturity. Colleges and universities should control financial risks within the effective scope of control to reduce the financial risks of universities and banks to a certain extent.

Intensify Overall Budget Management and Avoid Financial Risk Effectively. Bank loans should be incorporated into the budget management system of colleges and universities. The balance model of university financial budget should be: the amount of loans in the amount of revenue budget $=$ the amount of annual budget expenditure + the expected repayment amount. Establish a new financial relationship of "balanced cash flow balance". When budgeting, we must combine the actual situation of the university development plan to make it real and reasonable. Colleges and universities should guard against financial risks to ensure the funds safety and stabilize the economic order.

Enhance the Quality of Financial Personnel and Identify and Prevent Financial Risk Actively. Encourage financial personnel to change the idea from computing to management. Financial personnel should have a certain sense of management responsibility to analyze information and solve information from the perspective of managers. Regularly organize financial training and constantly update relevant policies and documents issued by the state. Improve the ability of managers to identify risks, prevent risks and control risks. Financial staff need to have certain professional skills and qualifications.

Strengthen Management System Construction of Financial Risk and Establish Risk Management Organization and Management Core. The university financial risk involves the university leader, each functional department and the teaching department and the teaching staff. The content of financial risk involves raising the fund, investing the project, distributing the profit. Make sure we have a thorough consideration of how to build the entire system properly. We must establish the financial risk management institutions, which are attended by university leaders and the financial, auditing and other related departments. The university should construct an efficient operation mechanism of financial risk management. The financial risk early warning mechanism of university should include the following contents: the organization and system guarantee mechanism, the information transmission and responsibility mechanism, the risk identification and evaluation mechanism and the risk countermeasure decision and execution mechanism.

\section{Acknowledgements}

This paper is one of the results the "Research on Early-warning and Countermeasures of Financial Risk in Universities" (Item No. j2cwC2171030), which is the "Project of Autonomous Choice of Social Science and Key Project of Higher Education Management of Fundamental Research Funds for the Central Universities in South China University of Technology in 2017”.

\section{References}

[1] Yan Xia, Wen Yongjun, On Financial Risk Prevention of Universities under Internal Control Perspective [J]. Journal of Southwest University of Science and Technology, 2016, 33(6): 66-69.

[2] Pei Xin, Research on the Issues of Tax Revenue Risks in Financial Administration of China Colleges and Universities [J]. The Guide of Science \& Education, 2016(11): 27-28.

[3] Song Wei, Wang Qian, Research on Financial Risk Management of Colleges and Universities Based on ERM [J]. Electronic Science and Technology, 2017, 30(3): 53-56. 
[4] Wang Xiaohua, Li Tuo, The Factors and Control of Financial Risk in the Colleges and Universities [J]. Business Economy, 2014(11): 123-125. 